\title{
GMR
}

\section{Genetic diversity of Desmanthus sp accessions using ISSR markers and morphological traits}

\author{
J.C. Costa ${ }^{1}$, G.G.M. Fracetto ${ }^{2}$, F.J.C. Fracetto ${ }^{2}$, M.V.F. Santos ${ }^{3}$ and \\ M.A. Lira Júnior ${ }^{2}$ \\ ${ }^{1}$ Instituto Federal de Pernambuco, Vitória de Santo Antão, PE, Brasil \\ ${ }^{2}$ Departamento de Agronomia, Universidade Federal Rural de Pernambuco, \\ Recife, PE, Brasil \\ ${ }^{3}$ Departamento de Zootecnia, Universidade Federal Rural de Pernambuco, \\ Recife, PE, Brasil \\ Corresponding author: M.A. Lira Júnior \\ E-mail: mariolirajunior@gmail.com
}

Genet. Mol. Res. 16 (2): gmr16029667

Received March 14, 2017

Accepted May 2, 2017

Published May 31, 2017

DOI http://dx.doi.org/10.4238/gmr16029667

Copyright $(2017$ The Authors. This is an open-access article distributed under the terms of the Creative Commons Attribution ShareAlike (CC BY-SA) 4.0 License.

\begin{abstract}
Desmanthus is a genus of forage legumes with high nutritional value, productive potential, and ability to obtain nitrogen in association with diazotrophic bacteria. The use of accurate techniques for genotype identification and characterization is essential for breeding programs. Morphological markers are widely used to know the genetic diversity and the molecular markers are fundamental in these studies. We investigated the genetic diversity among Desmanthus sp genotypes in Pernambuco (Brazilian Northeast State), using morphological traits and ISSR markers. Morphological and molecular characterizations were performed in 18 and 26 accessions, respectively, in plants belonging to the germplasm bank of forage legumes of Universidade Federal Rural de Pernambuco (UFRPE), Academic Unit of Serra Talhada, PE, Brazil. Eight ISSR primers were selected, and 95 loci were generated, with polymorphism of $95.79 \%$. The allele number observed was 1.958 , where the effective number was 1.359 , and the Nei diversity genetic
\end{abstract}

Genetics and Molecular Research 16 (2): gmr16029667 
index was 0.226 . About the morphological markers, seed number was the variable that most contributed to the genetic divergence. A large amount of genetic diversity was observed among Desmanthus species, occurring spontaneously in Pernambuco, Brazil. Thus, the variability found in morphological and ISSR markers is importance for the improvement of Desmanthus spp. Our findings showed that $17 \mathrm{~L}, 27 \mathrm{~L}$, $25 \mathrm{~F}, 22 \mathrm{~F}, 19 \mathrm{~S}, 13 \mathrm{Au}$, and $28 \mathrm{G}$ accessions could be used in breeding programs to explore the maximum genetic divergence.

Key words: Molecular markers; Morphological markers; Breeding programs

\section{INTRODUCTION}

Desmanthus is a genus of forage legumes occurring throughout America and has great potential for improved pasture and animal production (Rangel and Gardiner, 2009). These plants are mainly used as fodder because they have high palatability and large seed production (Fontenele et al., 2007, 2009).

In the Brazilian Northeast, D. pernambucanus L. Thell predominates (Pengelly and Liu, $2001)$, which is autogamous $(2 \mathrm{n}=26$ chromosomes), originating in South America, probably in Northeast Brazil (Santos-Garcia et al., 2012). These species are shrub-like, drought resistant, and have a high capacity to obtain nitrogen by association with diazotrophic bacteria, estimating about $30 \mathrm{~kg} \mathrm{~N}$ ha/year coming from biological nitrogen fixation (Freitas et al., 2011).

Although some studies have evaluated the response of Desmanthus species to the cut (Trujillo et al., 1996; Gonzalez-V et al., 2005; Diniz Neto et al., 2013), the cultivation of this plant in Northeast Brazil is non-existent. In the semiarid region of Pernambuco, Desmanthus sp occurs in different soil types, as well as different environmental characteristics (Queiroz, 2012). Besides, genotypes collected in this region show desirable morphological and productive characteristics for forage plants (Calado et al., 2016).

To initiate a breeding program, it is essential to know the genetic variability within the population (Melo et al., 2011). The genetic diversity evaluation among germplasm accessions results in information from potential parents to be used in breeding programs, allowing the duplicate identification and the exchange of germplasm among researchers (Martins et al., 2012).

The use of accurate techniques for identifying and characterizing of genotypes is essential for breeding programs and protection of cultivars. Morphological markers are widely used; however, they may present low efficiency in the assessment of available variability (Silva et al., 2013). On the other hand, molecular markers are highly accurate because they detect differences in DNA level and exhibit sufficient polymorphism to discriminate genotypes (Vieira et al., 2015).

ISSR (inter-simple sequence repeat) molecular markers is an excellent tool for the genetic diversity analysis and characterization of accessions and cultivars of several species due to the high degree of polymorphism, reproducibility and low cost (Salazar-Laureles et al., 2015; Brito et al., 2016; Silva et al., 2016).

The ISSR molecular markers use repeated and short sequences of DNA to amplify anonymous loci and do not require prior knowledge of the genome. Because these sequences are dominant loci, it is not possible to distinguish heterozygotes from homozygotes. However,

Genetics and Molecular Research 16 (2): gmr16029667 
multiple loci can be produced from each PCR (polymerase chain reaction) amplification (Goulão and Oliveira, 2001).

Thus, our study aimed to perform the morphological and molecular characterization of Desmanthus sp accessions. Thereby, we investigated the genetic diversity using ISSR markers, unprecedentedly for this genus on literature.

\section{MATERIAL AND METHODS}

The morphological characterization was conducted in 16 accessions belonging to the forage legume germplasm bank from the Universidade Federal Rural de Pernambuco Academic Unit of Serra Talhada, PE (Table 1). The morphological characters related to the plant were: pod number per bunch; growth habit; leaf number per branch; branch number; plant height; stem diameter; leaflet number per leaf; seed number.

Table 1. Desmanthus sp accessions and their respective accession numbers, collection city, soil type, latitude, longitude, and altitude.

\begin{tabular}{|c|c|c|c|c|c|}
\hline Identification & City & Soil type & Latitude & Longitude & Altitude \\
\hline $58 \mathrm{~F}$ & Bom Jardim & Entisol & $35^{\circ} 31^{\prime} 270^{\prime \prime}$ & $7^{\circ} 48^{\prime} 187^{\prime \prime}$ & $163 \mathrm{~m}$ \\
\hline $94 \mathrm{~F}^{*}$ & Bom Jardim & Vertisol & $35^{\circ} 41^{\prime} 129^{\prime \prime}$ & $7^{\circ} 50^{\prime} 151^{\prime \prime}$ & $335 \mathrm{~m}$ \\
\hline $22 \mathrm{~F}^{*}$ & Bom Jardim & Alfisol & $35^{\circ} 32^{\prime} 684^{\prime \prime}$ & $7^{\circ} 47^{\prime} 466^{\prime \prime}$ & $297 \mathrm{~m}$ \\
\hline $25 \mathrm{~F}^{*}$ & Bom Jardim & Alfisol & $35^{\circ} 32^{\prime} 684^{\prime \prime}$ & $7^{\circ} 47^{\prime} 466^{\prime \prime}$ & $297 \mathrm{~m}$ \\
\hline $21 \mathrm{~F}^{*}$ & Bom Jardim & Aridsol & $35^{\circ} 32^{\prime} 684^{\prime \prime}$ & $7^{\circ} 47^{\prime} 466^{\prime \prime}$ & $297 \mathrm{~m}$ \\
\hline $20 \mathrm{~F}^{*}$ & Bom Jardim & Aridsol & $35^{\circ} 33^{\prime} 679^{\prime \prime}$ & $7^{\circ} 48^{\prime} 632^{\prime \prime}$ & $300 \mathrm{~m}$ \\
\hline $28 \mathrm{G}^{*}$ & Santa Cruz do Capibaribe & Entisol & $36^{\circ} 14^{\prime} 831^{\prime \prime}$ & $07^{\circ} 53^{\prime} 504^{\prime \prime}$ & $509 \mathrm{~m}$ \\
\hline $7 \mathrm{G}$ & Santa Cruz do Capibaribe & Aridsol & $38^{\circ} 44^{\prime} 70^{\prime \prime}$ & $7^{\circ} 94^{\prime} 58^{\prime \prime}$ & $448 \mathrm{~m}$ \\
\hline $235 \mathrm{C}^{*}$ & Sertânia & Ultisol & $37^{\circ} 12^{\prime} 159^{\prime \prime}$ & $8^{\circ} 05^{\prime} 186^{\prime \prime}$ & $581 \mathrm{~m}$ \\
\hline $65 \mathrm{~F}^{*}$ & Sertânia & Ultisol & $35^{\circ} 31^{\prime} 719^{\prime \prime}$ & $7^{\circ} 46^{\prime} 314^{\prime \prime}$ & $231 \mathrm{~m}$ \\
\hline $100 \mathrm{C}^{*}$ & Sertânia & Aridsol & $37^{\circ} 18^{\prime} 163^{\prime \prime}$ & $8^{\circ} 04^{\prime} 039^{\prime \prime}$ & $559 \mathrm{~m}$ \\
\hline $19 \mathrm{~S}^{*}$ & Serra Talhada & Entisol & $38^{\circ} 26^{\prime} 65^{\prime \prime}$ & $7^{\circ} 95^{\prime} 71^{\prime \prime}$ & $444 \mathrm{~m}$ \\
\hline $17 \mathrm{~L}^{*}$ & Jataúba & Aridsol & $36^{\circ} 26^{\prime} 884^{\prime \prime}$ & $07^{\circ} 59^{\prime} 198^{\prime \prime}$ & $517 \mathrm{~m}$ \\
\hline $16 \mathrm{~L}^{*}$ & Jataúba & Aridsol & $36^{\circ} 27^{\prime} 227^{\prime \prime}$ & $07^{\circ} 59^{\prime} 243^{\prime \prime}$ & $519 \mathrm{~m}$ \\
\hline $92 \mathrm{~L} *$ & Jataúba & Entisol & $36^{\circ} 29^{\prime} 058^{\prime \prime}$ & $08^{\circ} 07^{\prime} 084^{\prime \prime}$ & $546 \mathrm{~m}$ \\
\hline $45 \mathrm{~L}^{*}$ & Jataúba & Aridisol & $36^{\circ} 23^{\prime} 980^{\prime \prime}$ & $07^{\circ} 58^{\prime} 083^{\prime \prime}$ & $490 \mathrm{~m}$ \\
\hline $15 \mathrm{~L}$ & Jataúba & Aridsol & $36^{\circ} 27^{\prime} 227^{\prime \prime}$ & $07^{\circ} 59^{\prime} 243^{\prime \prime}$ & $519 \mathrm{~m}$ \\
\hline $27 \mathrm{~L}^{*}$ & Jataúba & Aridsol & $36^{\circ} 26^{\prime} 884^{\prime \prime}$ & $07^{\circ} 59^{\prime} 198^{\prime \prime}$ & $517 \mathrm{~m}$ \\
\hline $50 \mathrm{~J}$ & Petrolina & Ultisol & $40^{\circ} 19^{\prime} 086^{\prime \prime}$ & $09^{\circ} 04^{\prime} 875^{\prime \prime}$ & $373 \mathrm{~m}$ \\
\hline $31 \mathrm{D}$ & Caetés & Ultisol & $38^{\circ} 39^{\prime} 34^{\prime}$ & $7^{\circ} 99^{\prime} 14^{\prime \prime}$ & $452 \mathrm{~m}$ \\
\hline $13 \mathrm{AU}^{*}$ & Austrália & & & & \\
\hline $10 \mathrm{AU}$ & Austrália & & & & \\
\hline
\end{tabular}

All accessions were characterized by ISSR. *Accessions characterized morphologically and by ISSR.

The data were standardized using the following formula: $\mathrm{x}=$ (species mean - general mean) / standard deviation. Principal component analysis was used to identify the variables that most contributed to the data variation. A cluster analysis was performed to evaluate the similarity degree among the species studied, using Euclidean distance as a unit of measure. These analyses were performed through the Genes program (Cruz, 2013).

For molecular characterization, 22 accessions were used. For DNA extraction, young leaves were collected following the methodology adjusted for this species by Pengelly and Liu (2001). The extracted DNA was quantified by comparison with lambda standards (Invitrogen, Carlsbad, CA, USA) of concentrations known $(300,500$, and $100 \mathrm{ng} / \mu \mathrm{L})$ on $0.8 \%$ agarose gel. The purity integrity of the DNA samples was confirmed in a spectrophotometer under UV light $(260 / 280 \mathrm{~nm})$. 
For molecular analyses, 15 ISSR primers were used from a set produced by the University of British Columbia, Vancouver, Canada (Table 2). The $25-\mu \mathrm{L}$ reaction mixtures contained 1X PCR buffer (Invitrogen), $1.5 \mathrm{mM} \mathrm{MgCl}_{2}, 0.8 \mu \mathrm{M}$ primer, $1 \mathrm{U}$ Platinum Taq DNA Polymerase (Invitrogen), $0.25 \mu \mathrm{M}$ of each dNTP (Invitrogen), $25 \mathrm{ng}$ DNA template, and sterile distilled water to the total volume of $25 \mu \mathrm{L}$.

Table 2. ISSR primers selected for Desmanthus sp genotypes, sequence, total fragment number per primer, polymorphism percentage (LP), allele numbers $\left(N_{\mathrm{A}}\right)$, the effective number of alleles $\left(N_{\mathrm{E}}\right)$, Shannon index (I), and Nei genetic diversity $\left(H_{\mathrm{E}}\right)$.

\begin{tabular}{l|l|c|c|c|c|c|c}
\hline Primer & Sequence & Loci & $\%$ LP & $N_{\mathrm{A}}$ & $N_{\mathrm{E}}$ & $\mathrm{I}$ & $H_{\mathrm{E}}$ \\
\hline UBC 1 & ACACACACACACACACT & 10 & $90 \%$ & 1.888 & 1.442 & 0.387 & 0.254 \\
\hline UBC 2 & GAGSGSGAGAGAGAGAT & 12 & $100 \%$ & 2.00 & 1.145 & 0.449 & 0.289 \\
\hline UBC 808 & AGAGAGAGAGAGAGAGC & 7 & $100 \%$ & 2.00 & 0.132 & 0.317 & 0.192 \\
\hline UBC 810 & GAGAGAGAGAGAGAGAT & 16 & $100 \%$ & 2.00 & 1.402 & 0.389 & 0.248 \\
\hline UBC 812 & GAGAGAGAGAGAGAGAA & 15 & $95.5 \%$ & 1.933 & 1.523 & 0.456 & 0.303 \\
\hline UBC 834 & AGAGAGAGAGAGAGAGYT & 13 & $92.3 \%$ & 1.923 & 1.304 & 0.316 & 0.196 \\
\hline UBC 845 & CTCTCTCTCTCTCTCTRG & 8 & $100 \%$ & 2.00 & 1.225 & 0.309 & 0.179 \\
\hline UBC 888 & BDBCACACACACACACA & 14 & $92.8 \%$ & 1.928 & 1.366 & 0.357 & 0.255 \\
\hline Total & & 95 & $95.8 \%$ & 1.958 & 1.359 & 0.361 & 0.226 \\
\hline
\end{tabular}

DNA amplifications were performed on thermocycler MJ Reseach, Inc., PTC100 Programmable Thermal Controller (Watertown, USA) under the following conditions: $94^{\circ} \mathrm{C}$ for $1 \mathrm{~min}$ (initial denaturation), followed by 35 cycles of $94^{\circ} \mathrm{C}$ for $30 \mathrm{~s}, 55^{\circ} \mathrm{C}$ for $1 \mathrm{~min}$, and $72^{\circ} \mathrm{C}$ for $1 \mathrm{~min}$ with a final extension step at $72^{\circ} \mathrm{C}$ for $5 \mathrm{~min}$ (Santos-Garcia et al., 2012).

The amplification products were separated on a $2 \%$ agarose gel stained with Syber Gold (Invitrogen), using the 100-bp marker (Invitrogen) and visualized under ultraviolet light and recorded on the digital photo documentation Vilber Lourmat. The polymorphisms obtained using ISSR were tabulated according to the presence (1) or absence (0) of bands.

Genetic diversity was estimated using the GenAlex 6.5 software (Peakall and Smouse, 2012), with the analysis of the observed number of alleles $\left(N_{\mathrm{A}}\right)$, an effective number of alleles $\left(N_{\mathrm{E}}\right)$, Nei genetic diversity $\left(H_{\mathrm{E}}\right)$, and Shannon index (I). Similarity coefficients were calculated using the Jaccard index (Jaccard, 1908) and the Genes program (Cruz, 2013) was used to construct a dendrogram, using the unweighted pair group method with arithmetic mean (UPGMA).

\section{RESULTS AND DISCUSSION}

About the morphoagronomic markers, the seed number was the variable that most contributed to the genetic divergence, with $60.31 \%$, followed by the branch number with a relative contribution of $30.34 \%$ (Table 3). Descriptors with the greatest contribution to divergence are the most important for the breeding program. These descriptors support to select the parents for the creation of segregating populations with a greater probability of success through the combination of these genotypes (Oliveira et al., 2016).

The accession clustering demonstrates eight formations of groups considering the mean dissimilarity of $62.5 \%$ (Figure 1). The same grouping was also suggested by the Tocher grouping. The first group is formed only for accessions collected in Jataúba, 16L, 92L, 45L, and $17 \mathrm{~L}$. The second group isolated $25 \mathrm{~F}$ access and the third isolated $22 \mathrm{~F}$, both collected in Bom Jardim. The fourth group had $94 \mathrm{~F}$ and $65 \mathrm{~F}$ accessions from Bom Jardim in one branch, and $100 \mathrm{C}$ accession from Sertânia in another branch.

Genetics and Molecular Research 16 (2): gmr16029667 
Table 3. Relative importance of eight descriptors for genetic divergence in Desmanthus spp.

\begin{tabular}{l|c|c}
\hline Characters & S.j & S.j (\%) \\
\hline Pod number per bunch & 223.0 & 0.47 \\
\hline Growth habit & 80.0 & 0.16 \\
\hline Leaf number per branch & 175.0 & 0.36 \\
\hline Branch number & 14812.0 & 30.34 \\
\hline Plant height & 121.92 & 0.25 \\
\hline Stem diameter & 1997.08 & 4.09 \\
\hline Leaflet number per leaf & 1815.0 & 3.72 \\
\hline Seed number per pod & 29591.0 & 60.31 \\
\hline
\end{tabular}

'S.j: contribution of variables to mean Euclidean distance between genotypes i and i'.



Figure 1. Morphological dissimilarity dendrogram of 16 Desmanthus sp accessions belonging to the germplasm bank from Universidade Federal Rural de Pernambuco, Academic Unit of Serra Talhada, PE.

The $27 \mathrm{~L}$ accession was isolated in the fifth group, being the only accession collected in Janaúba, outside the first group. The accessions 21F from Bom Jardim and 19S from Sertânia formed the sixth group. The seventh group consisted of 20F, 13AU, and $28 \mathrm{G}$ accessions, from Bom Jardim, Australia, and Santa Cruz do Capibaribe, respectively. The 13AU accession is the result of genotypes collected from Brazil, despite being cultivated in Australia, The last group consists of the isolation $235 \mathrm{C}$ accession from Sertânia. Thus, the morphological descriptors were able to form distinct groups that can be used for selection of parents for future breeding programs.

Plant selection based on morphological characters may be efficient, allowing breeding workers to use genetic variability to aggregate desirable alleles through crosses with superior genotypes (Silva et al., 2014). According to Silva et al. (2013), genetic variability means the possibility to direct the crosses using the most divergent accessions. Thus, the most divergent accessions $(235 \mathrm{C}, 42 \mathrm{~L}, 22 \mathrm{~F}, 25 \mathrm{~F}, 28 \mathrm{G}$, and $45 \mathrm{~L}$ ) can be used for future crosses to explore the variability of the Desmanthus sp collection.

In molecular characterization, a total of fifteen ISSR primers were tested, where eight were selected because they exhibited defined amplification patterns and high reproducibility. The primers selected to evaluate the 22 accessions amplified 95 DNA fragments (Table 2). The primer UBC808 resulted in the lowest number of amplified fragments (7) whereas the primer UBC810 generated the largest number of fragments (16) (Table 2).

The optimum number of bands estimated for Desmanthus sp was 84 loci (Figure 2). Thus, the total locus numbers found (94) was sufficient for the molecular characterization of 
the accessions. According to Kruskal (1964), when the stress value is equal to or less than 0.05 the estimates are accurate. For Copernicia prunifera, 76 bands were sufficient to estimate the genetic variability (Vieira et al., 2015).

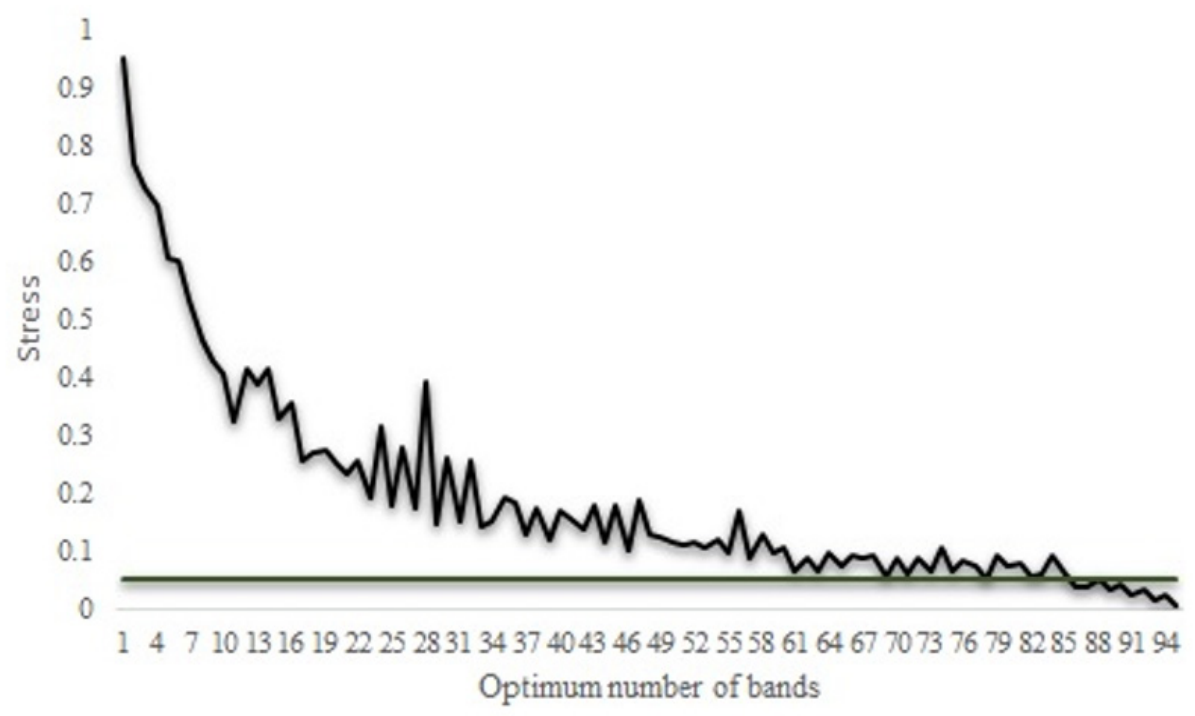

Figure 2. Estimates for increasing numbers of polymorphic ISSR markers and stress values, which indicate the ideal minimum number of bands to represent the genetic diversity in the Desmanthus sp accessions of Universidade Federal Rural de Pernambuco, Academic Unit of Serra Talhada, PE.

The primer UBC1 presented the lowest polymorphism (90\%), whereas the primers UBC02, UBC808, UBC810, and UBC834 showed 100\% polymorphism (Table 2). The mean of fragments per primer was 11.87 with polymorphism of $95.79 \%$. The data presented here were similar to other studies found using ISSR markers in other species. Souza Neto et al. (2014) analyzed the genetic diversity of Anthurium and obtained $71.43 \%$ of polymorphism with the UBC 845 primer, $81.82 \%$ for UBC 808 and $100 \%$ with UBC10. Accessions of the biribazeiro tree when submitted to ISSR markers, presented $81.3 \%$ of polymorphism, with a mean of 9 fragments per primer (Lorenzoni et al., 2014).

The $N_{\mathrm{E}}$ in our study was 1.359 (Table 2 ), and I was 0.361 . The $H_{\mathrm{E}}$ was 0.226 , considered moderate to low. The indices varied from 0 to 1 [ $(0$ represents the zero genetic diversity and 1 the maximum genetic diversity (Giustina et al., 2014)]. The primer UBC 845 presented values of 0.179 for Nei $(\mathrm{H})$ and 0.316 for I, with the lowest values in comparison to the other primers. The highest values were found when the primer UBC 812 was used with values of 0.456 for $\mathrm{H}$ and 0.303 for I. Our values were similar to the ones reported in the literature for dominant markers (Vieira et al., 2015).

The ISSR markers enabled the differentiation among the Desmanthus sp accessions (Figure 3). The lowest genetic distance was observed between $58 \mathrm{~F}$ and $94 \mathrm{~F}$ accessions, collected from Bom Jardim, with a genetic distance of 0.37 . The most divergent accessions were $235 \mathrm{C}$ and $19 \mathrm{~S}$, collected at $132 \mathrm{~km}$, with a genetic distance of 0.82 . 


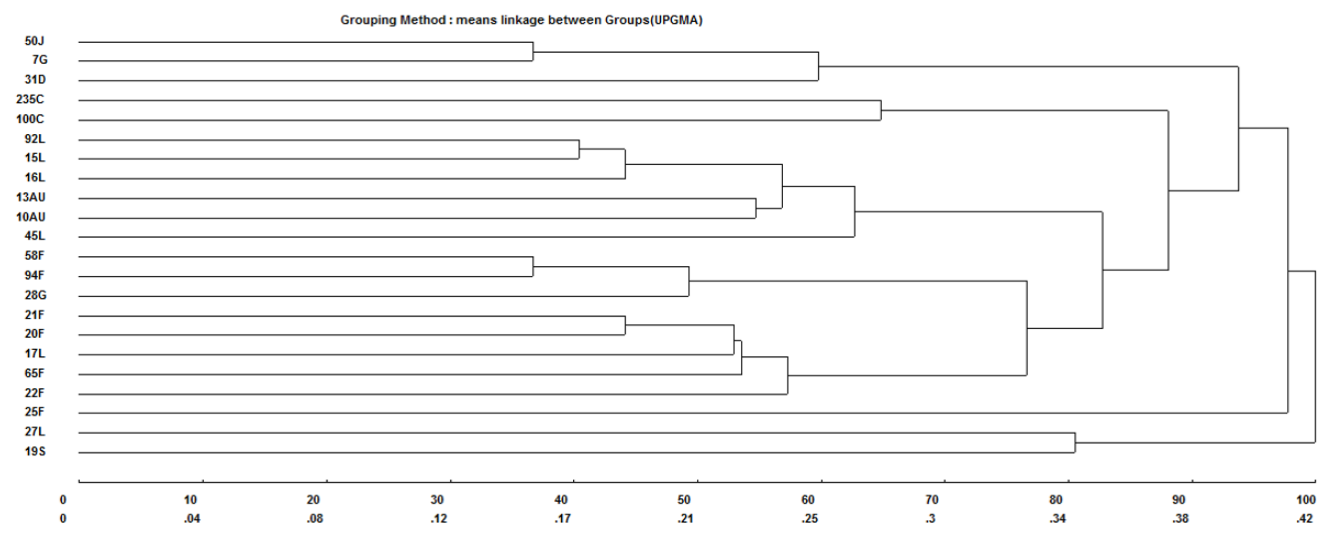

Figure 3. ISSR dendrogram dissimilarity of 22 Desmanthus sp accessions belonging to the germplasm bank of Universidade Federal Rural de Pernambuco, Academic Unit of Serra Talhada, PE.

The formation of six groups was observed, considering the dissimilarity of 0.75 . The first group had accessions 50J from Petrolina, and 7G from Santa Cruz do Capibaribe in one branch, and the $31 \mathrm{D}$ accession from Caetés was found to be more isolated. The second group was formed by the $235 \mathrm{C}$ and $100 \mathrm{C}$ accessions from Sertânia. The third group consisted of three branches. One branch grouped 92L, 15L, and 16L accessions, all coming from Jataúba and with altitude above $519 \mathrm{~m}$. In another branch were the two accessions coming from Australia and the last branch was formed by the 45L accession, also belonging to Jataúba, but with 490 $m$ in altitude.

The fourth group concentrated the highest accessions number, exclusively formed by accessions from Bom Jardim, with eight accessions distributed in two branches. One branch was constituted by the $58 \mathrm{~F}$ and $94 \mathrm{~F}$ accessions, both from Bom Jardim and with the greater similarity among all accessions of the collection. However, in the same branch there was the 28G accession coming from Santa Cruz do Capibaribe, but collected in an Entisol similar to the soil where $58 \mathrm{~F}$ accession was collected. The second branch was formed by $20 \mathrm{~F}, 21 \mathrm{~F}, 22 \mathrm{~F}$, $65 \mathrm{~F}$, and $17 \mathrm{~L}$ accessions and only $17 \mathrm{~L}$ was not collected in Bom Jardim.

In the fifth group, the $25 \mathrm{~F}$ accession was isolated. This accession was the only one collected in Bom Jardim and did not group with the other accessions collected in this city. The sixth and last group was represented by $27 \mathrm{~L}$ and $19 \mathrm{~S}$ accessions, coming from Jataúba and Serra Talhada, respectively. These accessions have $87 \%$ of the genetic distance, although they were in the same group.

All accessions were considered distinct and did not have duplicates. The occurrence of unidentified duplicates in germplasm banks makes it expensive and difficult to maintain the material, generating problems related to the organization and access of users to the genetic resource (Gonçalves et al., 2008).

Achieving dendrograms with similar clusters between morphological and molecular characters has not always been possible. With morphological data of mangaba accession, a dendrogram similar to that produced by the RAPD technique was not obtained (Silva et al., 2013). High correlations are not always obtained due to the interaction between genotype and environment, affecting their expression (Gomes Filho et al., 2010; Samal et al., 2011).

Genetics and Molecular Research 16 (2): gmr16029667 
Our selected primers are indicated for future research with genetic diversity and studies of Desmanthus sp populations. However, the apparent superiority of the UBC1, UBC2, UBC810, UBC812, and UBC888 primers was observed because they presented a high number of amplified fragments and Nei diversity indexes above the general average of the other primers. The grouping of some accessions was constant in both analyses, although they presented differences between the clusters of the morphological and molecular characterization. Besides, the grouping of most accessions corresponds to the geographic distribution.

Morphological characters and ISSR markers were efficient for the genetic diversity study in Desmanthus sp, revealing the diversity among the accessions. Thus, to exploit the maximum genetic divergence, the accessions $17 \mathrm{~L}, 27 \mathrm{~L}, 25 \mathrm{~F}, 22 \mathrm{~F}, 19 \mathrm{~F}, 19 \mathrm{~A}, 13 \mathrm{Au}$, and $28 \mathrm{G}$ can be used in future breeding programs, because they differ from other accessions by both morphological and molecular markers.

\section{ACNOWLEDGMENTS}

We thank Coordenação de Aperfeiçoamento de Pessoal de Nível Superior (CAPES, Brasília, Brazil) for the "Prodoutoral/CAPES" fellowship for J.C. Costa, Conselho Nacional de Desenvolvimento Científico e Tecnológico (CNPq, Brasília, Brazil), and Fundação de Amparo à Ciência e Tecnologia de Pernambuco (FACEPE, Pernambuco, Brazil) for research funding.

\section{REFERENCES}

Brito FA, Nizio DAC, Silva AVC, Diniz LEC, et al. (2016). Genetic diversity analysis of Varronia curassavica Jacq. accessions using ISSR markers. Genet. Mol. Res. 15: https://doi.org/10.4238/gmr.15038681.

Calado TB, Cunha MV, Teixeira VI, Santos MVF, et al. (2016). Morphology and productivity of "Jureminha" genotypes (Desmanthus spp.) under different cutting intensities. Rev. Caatinga 29: 742-752 https://doi.org/10.1590/198321252016v29n326rc.

Cruz CD (2013). GENES - a software package for analysis in experimental statistics and quantitative genetics. Acta Sci. Agron. 35: 271-276 https://doi.org/10.4025/actasciagron.v35i3.21251.

Diniz Neto MA, Vasconcelos RCM, Cavalcante LF, Pimenta Filho EC, et al. (2013). Disponibilidade de dois solos e diferentes idades de corte no comportamento agronômico de Jureminha. Rev. Cienc. Agron. 44: 24-33 https://doi. org/10.1590/S1806-66902013000100004.

Fontenele ACF, Aragão WM and Rangel JHA (2007). Biometria de frutos e sementes de Desmanthus virgatus (L) Willd nativas de Sergipe. Rev. Bras. Biocienc. 5: 252-254.

Fontenele ACF, Aragão WM, Rangel JHA and Almeida AS (2009). Leguminosas tropicais: Desmanthus virgatus (L.) Wild. Uma forrageira promissora. Rev. Bras. Agrociênc. 15: 121-123 10.18539/cast.v15i1-4.1998.

Freitas ADS, Silva TO, Menezes RSC, Sampaio EVSB, et al. (2011). Nodulação e fixação de nitrogênio por forrageiras da caatinga cultivadas em solos do semiárido paraibano. Rev. Bras. Zootec. 40: 1856-1861 https://doi.org/10.1590/ S1516-35982011000900003.

Giustina LD, Luz LN, Vieira FS, Rossi FS, et al. (2014). Population structure and genetic diversity in natural populations of Theobroma speciosum Willd. Ex Spreng (Malvaceae). Genet. Mol. Res. 13: 3510-3519 https://doi.org/10.4238/2014. February.14.5.

Gomes Filho A, Oliveira JG, Viana AP, Siqueira APO, et al. (2010). Marcadores moleculares RAPD e descritores morfológicos na avaliação da diversidade genética de goiabeiras (Psidium guajava L.). Acta Sci. Agron. 32: 627-633 https://doi.org/10.4025/actasciagron.v32i4.4720.

Gonçalves LSA, Rodrigues R, Sudré CP, Bento CS, et al. (2008). Divergência genética em tomate estimada por marcadores RAPD em comparação com descritores multicategóricos. Hortic. Bras. 26: 364-370 https://doi.org/10.1590/S0102$\underline{05362008000300014 .}$.

Gonzalez-V EA, Hussey MA and Ortega-S JA (2005). Nutritive value of Desmanthus associated with kleingrass during the establishment year. Rangeland Ecol. Manag. 58: 308-314 https://doi.org/10.2111/1551-5028(2005)58[308:NVO DAW]2.0.CO;2.

Genetics and Molecular Research 16 (2): gmr16029667 
Goulão L and Oliveira CM (2001). Molecular characterization of cultivars of apple (Malus x domestica Borkh.) using microsatellite (SSR and ISSR) markers. Euphytica 122: 81-89 https://doi.org/10.1023/A:1012691814643.

Jaccard P (1908). Nouvelles recherches sur la distribution florale. Bull. Soc. Vaud. Sci. Nat. 44: 223-270.

Kruskal JB (1964). Multidimensional scaling by optimizing goodness of fit to a no metric hypothesis. Psychometrika 29: 1-27 https://doi.org/10.1007/BF02289565.

Lorenzoni RM, Soares TCB, Santiago VF, Silva JA, et al. (2014). Utilização de marcadores ISSR na avaliação da divergência genética entre acessos de biribazeiro. Rev. Bras. Frutic. 36: 251-257 https://doi.org/10.1590/S010029452014000500029.

Martins GV, Martins LSS, Veasey EA, Lederman IE, et al. (2012). Diversity and genetic structure in natural populations of Hancornia speciosa var. speciosa Gomes in northeastern Brazil. Rev. Bras. Frutic. 34: 1143-1153 https://doi. org $110.1590 / \mathrm{S} 0100-29452012000400023$.

Melo RA, Resende LV, Menezes D, Beck APA, et al. (2011). Genetic similarity between coriander genotypes using ISSR markers. Hortic. Bras. 29: 526-530 https://doi.org/10.1590/S0102-05362011000400014.

Oliveira RS, Queiróz MA, Romão RS, Silva GC, et al. (2016). Genetic diversity in accessions of Stylosanthes spp. using morphoagronomic descriptors. Rev. Caatinga 29: 101-112 https://doi.org/10.1590/1983-21252016v29n112rc.

Pengelly BC and Liu CJ (2001). Genetic relationships and variation in the tropical mimosoid legume Desmanthus assessed by random amplified polymorphic DNA. Genet. Resour. Crop Evol. 48: 91-99 10.1023/A:1011234913710.

Peakall R and Smouse PE (2012). GenAlEx 6.5: genetic analysis in Excel. Population genetic software for teaching and research--an update. Bioinformatics 28: 2537-2539 https://doi.org/10.1093/bioinformatics/bts460.

Queiroz IV (2012). Ocorrência e germinação de sementes de Desmanthus sp. coletadas no semiárido pernambucano. Master's thesis, Universidade Federal Rural de Pernambuco, Recife. Available at [http://www.pgz.ufrpe.br/sites/ ww2.prppg.ufrpe.br/files/ildja_viviane_de_queiroz.pdf].

Rangel JHA and Gardiner CP (2009). Stimulation of wool growth by Desmanthus spp. as a supplement to a diet of Mitchell grass hay. Trop. Grassl. 43: 106-111.

Salazar-Laureles ME, Pérez-López DJ, González-Huerta A, Vázquez-García LM, et al. (2015). Genetic variability analysis of faba bean accessions using inter-simple sequence repeat (ISSR) markers. Chil. J. Agric. Res. 75: 122-130 https:// doi.org/10.4067/S0718-58392015000100017.

Samal KC, Jena RC, Swain SS, Das BK, et al. (2011). Evaluation of genetic diversity among commercial cultivars, hybrids and local mango (Mangifera indica L.) genotypes of India using cumulative RAPD and ISSR markers. Euphytica 76: 1-19 10.1007/s10681-011-0522-y.

Santos-Garcia MO, de Toledo-Silva G, Sassaki RP, Ferreira TH, et al. (2012). Using genetic diversity information to establish core collections of Stylosanthes capitata and Stylosanthes macrocephala. Genet. Mol. Biol. 35: 847-861 https://doi.org/10.1590/S1415-47572012005000076.

Silva AS, Cruz EMO, Reis RV, Ferreira CF, et al. (2013). Caracterização morfológica e molecular de genótipos de mangaba. Rev. Bras. Frutic. 35: 1093-1100 https://doi.org/10.1590/S0100-29452013000400021.

Silva BM, Rossi AAB, Dardengo JFE, Araújo VAAC, et al. (2016). Diversidade genética estimada com marcadores entre sequências simples repetidas em cultivos comerciais de cupuaçuzeiro. Cienc. Rural 46: 108-113 https://doi. org/10.1590/0103-8478cr20141634.

Silva JAG, Arenhardt EG and Gewehr E (2014). Variabilidade genética na busca de eficiência à produção de sementes e biomassa de capim Sudão. Rev. Bras. Eng. Agric. Ambient. 18: 19-24 https://doi.org/10.1590/S141543662014000100003.

Souza Neto JD, Soares TCB, Motta LB, Cabral PDS, et al. (2014). Molecular characterization of Anthurium genotypes by using DNA fingerprinting and SPAR markers. Genet. Mol. Res. 13: 4766-4775 https://doi.org/10.4238/2014.July.2.6.

Trujillo W, Pitman WD, Chambliss CG and Williams K (1996). Effects of height and frequency of cutting on yield, quality and persistence of Desmanthus virgatus. Trop. Grassl. 30: 367-373.

Vieira FA, Sousa RF, Silva RAR, Fajardo CG, et al. (2015). Diversidade genética de Copernicia prunifera com o uso de marcadores moleculares ISSR. Rev. Bras. Ciênc. Agrar. 10: 525-531.

Genetics and Molecular Research 16 (2): gmr16029667 